\title{
PROBLEMATIKA PENGAWASAN BANK PERKREDITAN RAKYAT SYARIAH DI PAMEKASAN
}

\author{
Zainal Abidin 1 \\ Prodi PBS STAIN Pamekasan \\ email:zainal.madura@gmail.com
}

\begin{abstract}
DPS It is urgent to give serious respond on the existing opinion that syariah banking is practically similar to conventional one. In fact, they are different in certain folds. One of the distinctive points is that the former has been equipped by a supervision board---Dewan Pengurus Syariah (DPS). This article exposes two things: firstly, it discusses how DPS operates its supervision function against BPR Syariah SPM in Pamekasan; secondly, it describes how DPS contributes its supervision function toward BPR Syariah SPM Pamekasan as an effort to keep the BPR Syariah be in the syariah (Islamic law) track. This research employs case study design of qualitative approach. This study results the followings---firstly, DPS has systematically supervised the BPRS SPM. The supervision is regularly undergone at least once a month toward the administration (contract transaction) and customer. Secondly, DPS BPRS SPM runs important contribution to enhance the syariah values of BPRS SPM. DPS both supervise and advise BPRS SPM to uphold the syariah principles in running the whole banking operations.
\end{abstract}

\section{Kata Kunci: Problematika, Pengawasan,}

Ada sebuah pernyataan umum yang sebetulnya belum dikaji secara akademis, namun sulit untuk ditolak karena belum juga ada bukti akademisnya bahwa bank syari'ah sama dengan bank konvensional.

Dari sisi akademis berdasarkan penelitian ditemukan tipologi pemikiran, yaitu Pertama, pemikiran yang sepaham dengan dengan aliran modernisme yang disebut dengan legal substantif yang menekankan pada aspek moral dan menomor duakan pengharaman riba dengan illat adanya kezaliman dalam riba; Kedua, pemikiran yang sepaham dengan Neo-Revivalisme yang disebut legal formal yang menitik beratkan pada bentuk lafal riba; Ketiga, pemikiran ala NeoRevivalisme yang disebut legal forced yang hampir sama dengan legal formal

1 Disarikan dari hasil penelitian oleh penulis sebagai ketua bersama Abd. Wahed dan Abdul Mukti Thabrani sebagai anggota.

jsh Jurnal Sosial Humaniora, Vol 5 No.1, Juni 2012 
hanya saja bedanya masih membolehkan menjadi nasabah bank konvensional selama belum ada alternatif karena darurat.

Hal senada diungkapkan oleh Abdullah Saeed yang mengatakan bahwa terdapat dua pimikiran dunia Islam terhadap bunga yaitu: Pertama, pemikran modernisme yang mengatkan bunga tidak riba. Kedua, pemikiran NeoRevivalisme yang menyatakan bunga adalah riba.2

Gambaran yang bisa memberi penjelasan tentang perbedaan antara bank syariah dengan bank konvensional, hal tersebut dapat dilihat pada diagram berikut ini:3

\begin{tabular}{|c|c|}
\hline \multicolumn{1}{|c|}{ Bank Islam } & Bank Konvensional \\
\hline $\begin{array}{c}\text { 1. Melakukan investasi yang halal } \\
\text { saja }\end{array}$ & 1. Investasi yang halal dan haram \\
\hline $\begin{array}{c}\text { 2. Berdasarkan prinsip bagi hasil, } \\
\text { jual beli atau sewa }\end{array}$ & 2. Memakai perangkat bunga \\
\hline $\begin{array}{c}\text { 3. Profit dan falah oriented } \\
\text { 4. Hubungan dengan nasabah dalam } \\
\text { bentuk kemitraan }\end{array}$ & $\begin{array}{c}\text { 4. Hubungan dengan nasabah } \\
\text { berbentuk debitur-kreditur }\end{array}$ \\
\hline $\begin{array}{c}\text { 5. Penghimpunan dan penyaluran } \\
\text { dana harus sesuai dengan fatwa } \\
\text { DPS. }\end{array}$ & 5. Tidak ada dewan yang sejenis \\
\hline
\end{tabular}

Salah satu perbedaan yang signifikan adalah adanya pengawasan dari pihak yang independen yaitu DPS dan DSN, dimana kinerja dewan itu perlu dikawal dan dibenahi untuk menuju situasi perbankan syari'ah yang ideal dan menjadi harapan kaum muslimin.

Oleh karena itu semua umat Islam mempunyai kewajiban untuk melakukan pengawasan baik secara langsung mapun tidak langsung sebagai wahana amar ma'ruf nahi munkar khususnya dalam bidang perbankan sebagai 
urat nadi perekonomian umat ini. Namun hal itu tidak mudah, karena sangat langka (untuk tidak mengatakan tidak ada) mencari orang maupun figur yang mengerti kedua entitas itu yaitu entitas perbankan yang memang njlimet dan komplit serta entitas syari'ah yang memerlukan kedalaman pemahaman tentang sumber-sumber dasar agama sebagai tuntunan dalam menjalani hidup dan kehidupan ini.

Kegiatan bank mempunyai risiko tinggi karena berususan dengan uang dalam jumlah yang sangat besar sehingga dapat menimbulkan niat orang-orang yang terlibat di dalamnya untuk melakukan kecurangan. Kalau kekhawatiran itu terjadi tentu dapat mengakibatkan kerugian bagi bank. Oleh karena itu dalam melaksanakan kontrol perlu didiciptakan suatu sistem kontrol yang berlapis-lapis (multilyer audit system).4

Ada beberapa audit yang dikenal dalam bank syari'ah, yaitu:

\section{Self control (pengendalian diri)}

Pengendalian atas diri sendiri merupakan lapisan pertama dan utama dalam diri setiap karyawan bank syari'ah, sehingga peran bagian sumber daya insani dalam memilih karyawan yang tepat merupakan syarat mutlak adanya peran lapisan kontrol yang pertama ini secara optimal.

Disamping itu sumber daya insani harus meyakini dan mengimani bahwa semua perbuatannya selalu direkam secara cermat oleh Allah SWT dan malaikat dan ia akan dimintai pertanggung jawabannnya kelak di kahirat.5

\section{Bulit-in control}

Selain self control, karyawan dalam melakukan tugas sehari-sehari tidak terlepas dari prosedur dan aturan main yang telah ditetapkan. Dalam sistem dan prosedur yang diciptakan secara tidak disadari oleh setiap karyawan dimasukkan unsur-unsur kontrol yang menyatu dalam prosedur tersebut.

\footnotetext{
${ }^{3}$ Muhammad Syafi'i Antonio, Bank Islam: Dari Teori Ke Praktik, (Jakarta: Gema Insani 2001), hlm. 34. Baca juga Materi Work Shop BPRS.

4 Muhammad Syafi'I Antonio, Muhammad SAW: The Super Leader Super Manager, (Jakarta: ProLM Centre, 2007), hlm. 209.

5 Hal ini sesuai dengan maksud Al Qur'an (Q.S. Qaaf:16-18, Al-an'am:59, Yasin:12, dan Al Baqarah: 255). Bandingkan dengan Syafi'i, Bank, hlm. 209-210.
}

jsh Jurnal Sosial Humaniora, Vol 5 No.1, Juni 
Unsur-unsur yang harus dipenugi dalam menciptakan pengendalian menyatu yang baik adalah adanya dual control, maker checker approval, limitation, segregation of duties, verification, dan lain sebagainya.6

\section{Internal Auditor}

Untuk dapat meyakinkan bahwa telah ada pengendalian diri dan pengendalin menyatu yang memadai, perlu adanya suatu ukuran dan penilaian dari pihak yang tidak terkait dengan kegiatan tersebut (independen). Selain itu manajemen juga harus mempunyai kemampuan dalam menganalisis efektivitas fungsi-fungsi kontrol yang ada melalui suatu auditor yang berlapis-lapis, seperti:

a. Bagian pengawasan data

Bagian ini sering disebut verifikator yaitu pemeriksa seluruh transaksi yang terjadi dimana salah satu produknya adalah program zero defect, yaitu suatu program audit yang memberikan peringatan kepada pelaksana atas kesalahankesalahan pembukuan yang terjadi. Dengan demikian secara bertahap kesalahan yang ada dapat terus ditekan dan mengarah kepada kesalahan nol ( tidak ada salah lagi).

Di samping itu bagian pengawasan data ini juga melakukan audit keuangan atas laporan keuangan khususnya melakukan pembuktian kebenaran material setiap pos yang ada yaitu dengan melakukan cash account, stock opname, rekonsilasi bank, proofing, dan lain sebagainya.

b. Auditor wilayah dan inspektur pengawasan Kedua pengawas ini berfungsi melakukan operasional audit disamping audit keuangan. Titik beratnya adalah pengujian secara menyeluruh atas berjalannya SPIN (sistem pengendalian internal) yang antara lain meliputi: aspek organisasi, yaitu memadai tidak sumber daya insani, praktik bank yang sehat dan unsur SPIN lainnya. Auditor wilayah adalah kepanjangan tangan dari inspektur pengawasan yang ada dikantor pusat. Sekalipun keberadaannya di kantor cabang, namun ia bertanggungjawab ke kantor pusat.

Hasil auditor ini adalah evaluasi/gambaran atas kondisi yang ada di lapangan dan praktik sehari-hari yang berlangsung dalam kegiatan bank. Auditor juga

${ }^{6}$ Stafi'i, Bank.., hlm. 210.

jsh Jurnal Sosial Humaniora, Vol 5 No.1, Juni 
bisa memberikan masukan kepada manajemnen dalam hal ini sebagai masukan untuk melakukan pembenahan, perbaikan, koreksi baik yang menyangkut sumber daya insani, sistem prosedur, maupun aspek manjerial. Dalam kegiatannya sehari-hari semua unsur pengawasan tetap tunduk dan patuh serta menjalankan Standar Pelaksanaan Fungsi Audit Intern Bank (SPAIB).7

\section{External auditor}

Auditor eksternal memberikan masukan kepada manajemen bank mengenai kondisi bank yang bersangkutan. Dari audit eksternal dapat diharapkan adanya suatu penilaian yang sangat netral terhadap objek-objek yang diperiksa. Audit eksternal biasanya dilakukan oleh BI, akuntan publik mupun pihak lainnya.8 Audit keuangan dan audit operasi juga dilaksanakan dalam pemerikasaan yang dilakukan oleh auditor untuk bank syari'ah. Khusus untuk pengujian kepatuhan disamping pertauran-peraturan, fatwa-fatwa dan notulen Dewan Pengawas Syari'ah harus dijadikan acuan.

Secara garis besar beberapa hal yang secara khususdilakukan dalam audit atas bank syari'ah adalah sebagai berikut:

a. Disamping pengungkapan kewajaran penyajian laporan keuangan, juga diungkapkan unsur kepatuhan syari'ah.

b. Perbedaan akunting yang menyangkut aspek produk baik sumber dana maupun pembiayaan.

c. Pemerikasaan distribusi profit.

d. Pengakuan penadapatan cash basis serta riil

e. Pengakuan beban secara actual basis

f. Dalam hubungan dengan bank koresponden khususnya koresponden depository, pengakuan pendapatan tetap harus menggunakan prinsip bagi hasil, jika tidak pendapatan atas bunga tidak boleh dicatat sebagai pendapatan.

g. Adanya pemeriksaan atas sumber dan penggunaan zakat

${ }^{7}$ Ibid.

${ }^{8}$ Syafi'i, Bank, hlm. 211.

jsh Jurnal Sosial Humaniora, Vol 5 No.1, Juni 
h. Revaluasi atas valuta asing dapat diakui apabila posisi debisa neto dalam posisi square. Dalam hal ini harus ada ketentuan tentang posisi tersebut yang dianggap square.

i. Adanya tindakan transaksi yang mengandung unsur-unsur yang tidak sesuai dengan syari'ah.

Berangkat dari audit tersebut maka fungsi dasar Bank Syari'ah (BS) secara umum sama dengan bank konvensional, sehingga prinsip pokok pengaturan dan pengawasan yang dikembangkan bagi sistem perbankan sebagian besar berlaku pula pada BS. Namun adanya sejumlah perbedaan yang cukup mendasar dalam filosofi dan prinsip operasional BANK SYARIAH mengakibatkan adanya perbedaan pengaturan dan pengawasan BANK SYARIAH.

Karakteristik khusus BANK SYARIAH yang mengakibatkan adanya perbedaan dalam pengaturan dan pengawasan terutama adalah:

1. Perlunya jaminan pemenuhan ketentuan dan ketaatan pada prinsip syariah dalam seluruh aktivitas bank syariah

2. Perbedaan karakteristik operasional khususnya akibat dari pelarangan bunga yang digantikan dengan skema PLS dengan instrumen nisbah bagi hasil.

Langkah-Langkah dalam pemenuhan prinsip syariah9

a. Menciptakan regulasi dan sistem pengawasan yang sesuai dengan karakteristik bank syariah

b. Menetapkan aturan tentang mekanisme pengeluaran setiap produk bank syariah yang memerlukan pengesahan (endorsement) dari DSN-MUI tentang kehalalan/kesesuaian produk dan jasa keuangan bank dengan prinsip syariah, c. Menerapkan sistem pengawasan baik untuk penilaian aspek kehatian-hatian dan kesesuaian operasional bank dengan ketentuan syariah dengan melibatkan Dewan Pengawas Syariah dan unsur pengawasan syariah lainnya

9 Muhammad Syafi'i Antonio, Bank Islam: Dari Teori Ke Praktik, (Jakarta: Gema Insani 2001), 30-33. Baca juga Setiawan Budi utomo, Peran DSN dan DPS dalam Perbankan Syari'ab dalam Kumpulan materi TOT perbankan syari'ah (Surabaya: IAIN Sunan Ampel, 2010), 9-18. Baca juga BI, Kamus Istilah Keuangan Dan Perbankan Syari'ah (jakarta: Direktorat perbankan syari'ah BI, 2006), 22-23. 


\section{Dewan Syari'ah Nasional10}

Dewan Syari'ah Nasional (DSN) adalah Dewan yang dibentuk oleh MUI yang bertugas \& memiliki kewenangan untuk memastikan kesuaian antara produk, jasa, dan kegiatan usaha bank dengan prinsip syariah.

Sesuai dengan substansi SK MUI Kep-98./MUI/III/2001 Tentang Susunan Pengurus Dewan Syariah Nasional MUI Masa Bakti Th.2000-2005 Tgl. 30 Maret 2001 maka kedudukan, status dan anggota DSN:

1. DSN merupakan bagian dari MUI

2. DSN membantu pihak terkait seperti Depkeu, BI dalam menyusun peraturan/ketentuan untuk LKS

3. Anggota DSN terdiri dari para ulama, praktisi dan pakar dalam bidang Terkait dengan muamalah syariah

4. Anggota DSN ditunjuk dan diangkat oleh MUI selama 5 tahun masa bakti Adapun Tugas-Tugas DSN:

1. Menumbuhkembangkan penerapan nilai-nilai syariah dalam aktivitas keuangan dan ekonomi

2. Mengeluarkan fatwa atas jenis-jenis kegiatan keuangan

3. Mengeluarkan fatwa atas produk $\&$ jasa keuangan syariah

4. Mengawasi penerapan fatwa yang telah dikeluarkan

\section{Sedangkan Wewenang DSN:}

1. Mengeluarkan fatwa yang mengikat DPS di masing-masing LKS dan menjadi dasar tindakan hukum pihak terkait

2. Mengeluarkan fatwa yang menjadi landasan bagi ketentuan/peraturan yang dikeluarkan oleh instansi yang berwenang seperti Depkeu dan BI

3. Memberikan rekomendasi dan/atau mencabut rekomendasi nama-nama yang akan duduk sebagai DPS pada LKS

4. Mengundang para ahli untuk menjelaskan masalah yang diperlukan dalam pembahasan ekonomi syariah, termasuk otoritas moneter/lembaga keuangan dalam maupun luar negeri

5. Memberikan peringatan kepada LKS atas penyimpangan dari fatwa DSN

${ }^{10}$ Setiawan Budi, Peran..

jsh Jurnal Sosial Humaniora, Vol 5 No.1, Juni 
6. Mengusulkan kepada instansi berwenang untuk mengambil tindakan apabila peringatan tidak diindahkan

Dewan Pengawas Syari'ah (DPS) adalah dewan yang bersifat independen yang dibentuk oleh DSN dan ditempatkan pada Bank yang melakukan kegiatan usaha berdasarkan prinsip syariah dgn fungsi yang diatur oleh DSN. Sedangkan Keanggotaan DPS diusulkan oleh Bank, disetujui oleh BI dan ditetapkan oleh DSN dan diangkat oleh RUPS

Beberapa ketentuan yang terkait dengan DPS, yaitu:

a. Bank Wajib membentuk \& memiliki DPS yang berkedudukan di KP-BS

b. BI mengatur persyaratan, tugas, wewenang dan kewajiban DPS

c. Keanggotaan DPS diusulkan oleh Bank, disetujui oleh BI dan ditetapkan oleh DSN sebelum diangkat oleh RUPS

d. DPS berfungsi mengawasi keg. usaha bank agar sesuai syariah Adapun Tugas, Wewenang dan Tanggung Jawab DPS:

a. Memastikan kesesuaian kegiatan operasional BPRS terhadap fatwa DSN

b. Menyampaikan lap. Min setiap 6 bulan ke Direksi, Dewan Komisaris, DSN dan BI

c. Menilai aspek syariah terhdp pedoman dan produk yang dikeluarkan BPRS

d. Memberikan opini syariah

e. Mengkaji produk dan jasa baru untuk dimintakan fatwa DSN

f. Meminta penjelasan langsung pada bank dan ikut pembahasan intern

Adapun fungsi dan peran DPS dalam Perbankan Syariah

Faktor utama pendorong keberadaan bank syariah adalah keinginan pengguna jasa utk secara kaffah menghindari larangan dan melaksanakan ketentuan syariah dalam seluruh aktivitas perbankan yang dilakukan.

Kunci keberhasilan dan kesinambungan eksistensi bank syariah adalah adanya ‘jaminan' dan kepercayaan pengguna jasa bahwa bank syariah melaksanakan norma dan prinsip syariah secara istiqomah.

Peran pemantauan, memberikan nasihat kesyariahan menjelaskan secara gamblang yang $h a q$ dan yang bathil adalah peran keulamaan yang tak tergantikan. 
Peran DPS sangat sentral dalam sistem jaminan 'shariah compliance' karena :

- Nasabah memiliki banyak keterbatasan keahlian, waktu dan akses informasi serta kewenangan masuk dalam operasional bank,

- Pengelola Bank memiliki kecenderungan memaksimal keuntungan serta mendorong kepraktisan yang terkadang mengabaikan aspek shariah compliance

- Unsur lainnya seperti. Internal Shariah Reviewer, External Shariah Auditor, lembaga advokasi konsumen syariah belum ada/efektif.

Sifat delegasi wewenang yang diberikan nasabah kepada DPS adalah amanah sehingga dimensi tanggung jawab DPS selain bersifat formal kelembagaan juga kepada Allah SWT.

Adanya sebuah pengawasan yang cukup sistemik tersebut tentunya akan menghasilkan sebuah prestasi yang menjanjikan dimasa yang akan datang. Oleh karena itu sebagai sebuah praktik keuangan yang relatif baru, yaitu sekitar 1 Mei 1992 dengan adanya Bank Muamalat Indonesia (BMI)11 maka pelaksanaan bank syari'ah masih perlu diawasi. Namun seharusnya tidak berhenti ditingkatan pengawasan melainkan harus ditindak lanjuti dengan proses sosialisasi di semua lini kehidupan baik masyarakat perbankan maupun mayarakat awam khususnya kaum muslimin.

Dalam hal sosialisasi ini sedikitnya ada empat peranan penting bagi para ulama sebagai penjaga nila-nilai syari'ah, yaitu:

1. Menjelaskan kepada masyarakat bahwa perbankan syari'ah pada dasarnya merupakan penerapan secara bertahap konsep fiqh muamalat, dimana fiqh ini menerangkan bagaimana manusia berhubungan dengan manusia dalam bidang harta benda, ekonomi, bisnis dan keuangan. Konsep tersebut telah begitu familiar dalam masyarakat kaum muslimin, namun ternyata konsep-konsep tersebut sulit untuk dipraktikkan dalam kehidupan sehari-hari khususnya di sektor perbankan.

2. Mengembalikan masyarakat pada fitrah alam dan fitrah usaha yang sebelumnya telah mengikuti konsep-konsep syari'ah. Fitrah tersebut disinyalir 
dirusak tatanannya oleh hadirnya liberalisasi sehingga memunculkan kapitalisme yang tidak terbendung.

3. Meluruskan konsep "cari duit yang haram susah apalagi yang halal", konsep ini sebenarnya berasal dari Machiavelli yang menghalalkan segala cara tanpa aturan etika dan norma hukum.

4. Membantu menyelamatkan perekonomian bangsa melalui pengembangan perbankan syari'ah.12

Melalui pintu ulama ini sebenarnya pengawasan dan sosialisasi bank syari'ah akan menemukan momentumnya namun perlu dipahami bahwa ulama miskin unformasi, miskin pengetahuan tentang sistem perbankan. Oleh karena itu kerja sama yang bersifat sinergi merupakan hal yang tidak bisa ditawar-tawar lagi sehingga pengawasan dan sosialisasi perbankan syari'ah bisa diharapakan lebih baik di masa yang akan datang.

Ada Beberapa Prinsip Operasional dalam Bank yang Syariah, yaitu:13

\begin{tabular}{|c|c|c|}
\hline Jenis Usaha & Produk/Jasa & Prinsip Syariah \\
\hline \multirow{4}{*}{$\begin{array}{c}\text { Penghimpun } \\
\text { Dana }\end{array}$} & Giro & Wadiah yad dhamamah \\
\cline { 2 - 3 } & Tabungan & $\begin{array}{c}\text { Wadiah yah Dhamamah wa } \\
\text { Mudharabah }\end{array}$ \\
\cline { 2 - 3 } & Deposito & Mudharabah \\
\cline { 2 - 3 } & Simpanan Khusus & Mudharabah Muqayyadah \\
\hline \multirow{3}{*}{$\begin{array}{c}\text { Penyaluran } \\
\text { Dana }\end{array}$} & Dana Tabungan & Qardh \\
\cline { 2 - 3 } & Penyertaan & $\begin{array}{c}\text { Musyarakah Muntahiyah bi Tamlik } \\
\text { (Ijarah wa Iqtina') }\end{array}$ \\
\cline { 2 - 3 } & Sewa Beli & $\begin{array}{c}\text { Mudharabah, Musyarakah } \\
\text { atau Murabaha }\end{array}$ \\
\cline { 2 - 3 } & Pembiyaan Modal Kerja & \\
\hline
\end{tabular}

11Bank Indonesia, Perbankan Syari'ah, Lebih Dari Sekedar Bank (Jakarta:BI, 2010), hlm. 13.

12Syafi'i, Bank...,237-238. Baca juga Mulya Siregar, Strategi BI Kembangkan Perbankan Syai'ah dalam Majalah Sharia Insight edisi Desember 2010, hlm. 47.

13Hari Sudarsono,Bank dan Leembaga Keuangan Syariab;,Deskripsi dan ilustrasi Ekonisia), 82. 


\begin{tabular}{|c|c|c|}
\hline Pembiayaan Proyek & $\begin{array}{c}\text { Mudharabah atau } \\
\text { Musyarakah }\end{array}$ \\
\cline { 2 - 3 } & $\begin{array}{c}\text { Pembiayaan Sektor } \\
\text { Pertanian }\end{array}$ & Bay' bi Salam \\
\cline { 2 - 3 } & $\begin{array}{c}\text { Pembiayaan untuk } \\
\text { Akuisisi Aset }\end{array}$ & Ijarah Muntahiyah bin Tamlik \\
\hline Pembiayaan Ekspor & Mudharabah, Musyarakah \\
& Anjak Piutang & Hurabaha \\
\cline { 2 - 3 } & Letter of Credit (LC) & Wakalah \\
\cline { 2 - 3 } & Garansi Bank & Kafalah \\
\cline { 2 - 3 } & Inkaso, Transfer & Wakalah dan Hiwalah \\
\hline Pinjaman Sosial & Qadrh al-Hasan \\
\hline Surat Berharga & Mudharabah, Qardh, Bay bi \\
& al-Dayn \\
\hline Safe Deposit Box & Wadiah Amanah, Ujrah \\
\hline Gadai & Rahn \\
\hline & & \\
\hline
\end{tabular}

Dalam ranah prosedur bank yang didasarkan pada prinsip syariah maka harus mempunyai prinsip-prinsip sebagai berikut:

Pertama, Prinsip Simpanan. Dalam prinsip simpanan ini dikenal dengan istilah $\mathrm{Al}$-Wadiah, yang maknanya adalah perjanjian antara pemilik barang (termasuk uang), dimana pihak penyimpan bersedia menyimpan dan menjaga keselamatan barang yang dititipkan kepadanya.14 Prinsip ini dikembangkan dalam bentuk produk simpanan, yaitu: Giri Wadi'ah dan tabungan Wadi'ah.

Kedua, Prinsip Bagi-hasil. Dalam prinsip ini dikenal tiga istilah: (i) Musyarakah, perjanjian kerjasama antara dua pihak atau lebih pemilik modal (uang atau barang) untuk membiayai suatu usaha. Keuntungan dari usaha tersebut dibagi sesuai dengan perjanjian antara pihak-pihak tersebut, yang tidak harus 
sama dengan pangsa modal masing-masing pihak. Dalam hal kerugian dilakukan sesuai dengan pangsa modal masing-masing 15 (ii) mudharabah, perjanjian antara pemilik modal (uang atau barang) dengan pengusaha. Dalam perjanjian ini pemilik modal bersedia membiayai sepenuhnya suatu proyek atau usaha dan pengusaha setuju untuk mengelola proyek tersebut dengan pembagian hasil sesuai dengan perjanjian. Pemilik modal tidak dibenarkan membuat usulan dan melakukan dan melakukan pengawasan. Apabila uasaha yang di awasi mengalami kerugian, maka kerugian tersebut sepenuhnya ditanggung pemilik modal, kecuali kerugian itu terjadi penyelewengan atau penyalah gunaan penguasa;16 (iii) Muzara'ah, memberikan lahan pertanian kepada si penggarap untuk di tanami dan di pelihara dengan imbalan tertentu (prosentase) dari hasil panen.17 Prinsip Mudharabah dijadikan dasar pengembangan produk tabungan dan deposito. Sementara prinsip Musyarakah dan Muzaraah di gunakan sebagai dasar pengembangan produk pembiayaan.

Ketiga, Prinsip Pengembalian Keuntungan, yang dapat disederhanakan jual beli, yaitu hak proses pemindahan hak milik barang atau aset dengan menggunakan uang sebagai media.18 macam-macam dari jal beli ini adalah: (i) $A l$ Musawamah, jual beli biasa dimana penjual memasang harga tanpa memberitahu si pembeli tentang berapa margin keuntungan yang diambilnya; (ii) At Tauliah, yaitu menjual dengan harga beli tanpa mengambil keuntungan sedikitpun, seolah si penjual menjadikan pembeli sebagai walinya (Tauliah) atasa barang atau aset; (iii) Al Murabahah, yaitu dengan menjual dengtan haga asal ditambah margin keuntungan tyang telah disepakati; (iv) Al Muwadhaah, yaitu menjual dengan harga yang lebih rendah dari harga beli, atau dengan kata lain Al Muwadhaah merupakan bentuk kebalikan dari Al Murabahah; (v) Al Muqayadhah, merupakan bentuk awal dari transaksi dimana barang ditukar dengan barang (barter); (vi) $\mathrm{Al}$ Mutlaq, yaitu bentuk jual beli biasa dimana barang ditukar dengan uang; Ash Sharf, adalah jual beli valuta asing dimana uang ditukar dengan uang (money

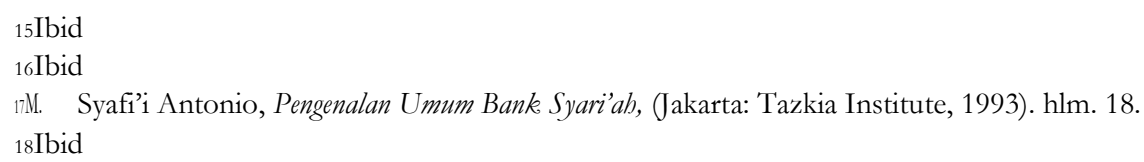


Exchange); (viii) Ba'i Bithaman Ajil, menjual dengan harga asal ditambah dengan margin keuntungan yang telah disepakati dan dibayar secara kredit;(ix) $B a^{\prime} i A s$ Salam, yaitu proses jual beli dimana pembayaran dilakukan secara advance manakala penyerahan barang dilakukan kemudian; (x) Ba'i Al-Istishna, yaitu kontrak order yang ditandatangani bersama antara pemesan dengan produsen untuk pembuatan suatu jenis barang tertentu. Prinsip ini dijadikan dasar pengembangan produk pembiayaan.

Keempat, Prinsip Sewa (Ijarah), yaitu perjanjian antara pemilik barang dengan penyewa yang memperbolehkan penyewa untuk memanfaatkan barang tersebut dengan membayar sewa sesuai dengan perjanjian kedua pihak. Setelah masa sewa berakhir maka barang akan dikembalikan kepada pemiliknya.19 Ada tiga jenis dari ijarah ini; (i) Ijarah Mutlaqah (Leasing), proses sewa menyewa yang biasa kita temui dalam kegiatan perekonomian sehari-hari; (ii) $B a^{\prime} i U t$ ta ’jiri (Hire Purchase) suatu kontrak sewa yang diakhiri dengan penjualan. Dalam kontrak ini pembayaran sewa telah diperhitungkan sedemikian rupa sehingga sebagian dari padanya merupakan pembelian terhadap barang secara angsur. (iii) Musarakah Mutanaqisah (Dekreaing Party-cipation). Kombinasi antara musyarakah dengan ijarah/perkongsian dengan sewa.20 Prinsip ini dijadikan dasar perkembangan produk pembiayaan.

Kelima. Prinsip pengambilan fee yang dapat dibagi menjadi empat; [a] $A l$ Kafalah/Guarante. Yakni suatu jaminan yang di berikan oleh penanggung (kafil) kepada pihak ketiga untuk memenuhi kewajiban pihak kedua yang ditanggungnya. Jenis-jenis kafalah adalah; (i) Kafalah Bi An Nafs. Jaminan dari sipeminjam (bank sebagai juridical personality dapat memberikan jaminan untuk maksud-maksud tertentu); (ii) Kafalah Bi Al Mal. Jaminan pembayaran barang atau pelunasan utang; (iii) Kafalah Bi Taslim. Dilakukan untuk menjamin dikembalikannya barang sewaan pada akhir masa kontrak (dapat dilakukan antar bank dengan leasing company terkait atas nama nasabah dengan mempergunakan depositnya di bank dan mengambil fee nya); (iv) Kafalah Bi Munjazah, jaminan

19Muhammad. Bank Syariab: Analisis...hlm. 23.

20ll. Syafi'i Antonio, Pengenalan.., hlm. 31-32.

jsh Jurnal Sosial Humaniora, Vol 5 No.1, Juni


mutlak yang tidak dibatasi oleh kurun waktu tertentu atau dihubungkannya dengan maksud dengan maksud-maksud tertentu; (v) Kafalah Al Mualaqagh, merupakan penyederhanaan dari kafalah al munjazah, yaitu jaminan dibatasi oleh kurun waktu dan tujuan-tujuan tertentu. [b] Al Wakalah, perjanjian pemberian kuasa kepada pihak lain yang ditunjuk untuk mewakilinya dalam melaksanakan suatu tugas/kerja atas nama pemberi kuasa.21 Jenis al wakalah ada tiga: (i) Wakalah Al Mutlaqah, mewakilkan secara mutlak tanpa batasan waktu atau urusan-urusan tertentu; (ii) Wakalah Al Muqayyadah, dalam kontrak ini pihak pertama menunjuk pihak kedua sebagai wakilnya untuk bertindak atas namanya dalam urusan-urusan tertentu; (iii) Wakalah Al aamah, bentuk Wakalah yang lebih luas dari Al Muqayyadah tetapi lebih sederhana dari Al Mutlaqah. [c] Hiwalah, pengalihan kewajiaban dari suatu pihak yang mempunyai kewajiban kepada pihak lain.22 [d] Al Ji'alah, suatu kontrak pihak pertama menjanjikan imbalan tertentu kepada pihak kedua atas pelaksanaan usah atau tugas. Prinsip ini dijadikan dasar pengembangan produk jasa layanan (service).

Keenam, prisip biaya administarsi (Al Qard Hasan/benevelon loan), yakni perjanjian pinjam meminjam uang atau barang dengan tujuan untuk membantu penerima pinjaman. Penerima pinjaman wajib mengembalikan hutangnya dalam jumlah yang sama dan apabila peminjam tidak mampu mengembalikan pada waktunya maka peminjam tidak boleh dikenai sanksi. Atas kerelaannya peminjam diperbolehkan memberikan imbalan kepada pemilik barang/uang. 23

Dalam konteks Pamekasan pengawasan bank syariah itu memerlukan penekanan yang serius karena disamping sebagai kota Gerbang Salam Pamekasan merupakan daerah yang menjadi acuan daerah lain di Madura. Hal itu dibuktikan banyak kantor pemerintahan pusatnya di Pamekasan misalnya BAKORWIL IV. Termasuk perbankan maka kantor pusatnya di Pamekasan.

Oleh karena itu dalam penelitian ini berusaha mengurai pengawasan syariah terhadap perbankan syariah yang ada di Pamekasan. Sebenarnya BPRS di Pamekasan ada dua yaitu BPRS Sarana Prima Membangun (SPM) dan BPRS

21Muhammad. Bank Syari'ab: Analisis... hlm. 24.

22ll. Syafi'i Antonio, Pengenalan, hlm. 12. 
Bhakti Sumekar, namun karena DPS itu ada di kantor pusat maka peneliti hanya memfokuskan pada BPRS SPM saja.

Dari uraian di atas sangat menarik untuk diteliti mengapa DPS yang merupakan ciri khas yang ada pada bank syariah sampai saat ini belum terdengar dengungannya. Berarti ada sebuah problem yang harus diketahui dengan harapan jika diketahui benang kusut itu bisa terurai sebenarnya dimana problema yang mengelilingi pengawasan bank syariah tersebut. Secara sistematis maslah yang akan diteliti dapat dirumuskan, yaitu: Pertama, Bagaimanakan operasionalisasi pengawasan oleh DPS terhadap BPR Syariah SPM di Pamekasan? Kedua, Bagaimana kontribusi DPS dalam ranah pengawasan BPR Syariah SPM Pamekasan sebagai usaha mensyari'ahkan BPR Syari'ah?

Dalam realita yang sederhana seperti di BPRS SPM akan tampak sebuah miniatur yang akan menjadi referensi problematika pengawasan sehingga mempunyai korelasi dengan bangunan citra bank syariah.

\section{Metode Penelitian}

Dalam penelitian ini pendekatan yang digunakan adalah adalah pendekatan kualitatif karena data yang dikumpulkan lebih banyak data kualitatif yaitu data yang disajikan dalam bentuk verbal bukan angka.24 Data tersebut diharapakan akan mampu merekam realitas di lapangan yang mendekati aslinya kemudian data itu akan diolah dan dinanlisis sebagai tujuan finalnya akan ditemukan tujuan penelitian ini.

Di samping itu adanya observasi dan interview mutlak digunakan dalam penelitian ini sebagai instrumen pengumpulan data dengan mencantumkan kisikisi pertanyaan sebagai pedoman wawancara agar wawancara berjalan dengan lancar dan berkualitas.

Jenis penelitian dalam penelitian ini adalah studi kasus karena mempunyai maksud untuk mengungkap problematika pengawasan DPS terhadap operasinalisasi Bank Pembiayaan Rakyat Syariah (BPRS) Sarana Prima Mandiri

23Muhammad. Bank Syari'ab: Analisis...12.

${ }^{24}$ Noeng Muhadjir, Metode Penelitian Kualitatif, (Yogyakarta: Rake Sarasin, 1996), 29.

jsh Jurnal Sosial Humaniora, Vol 5 No.1, Juni 
(SPM) di kantor pusat Pamekasan. Dengan sempitnya penelitian ini diharapkan dapat menemukan temuan yang cukup mendalam dan berarti.

Ada beberapa masalah yang bisa dikategorikan studi kasus, yaitu:

a. Sasaran penelitiannya berupa manusia, peristiwa latar dan dokumen. Sesuai dengan hal itu sasaran penelitiannya adalah Dewan Pengawas Syariah (DPS) dan Direksi.

b. Penelaahan secara mendalam sebagai suatu totalitas dan menjadi kesatuan yang saling bertautan satu sama lainnya. DPS dan Direksi merupakan satu kesatuan dalam satu Bank termasuk di BPRS SPM.25

Untuk menjawab apa yang ada dalam rumusan maslah maka penelitian ini berusaha menerangkan persoalan-persoalan yang ada sehingga penelitian ii bercorak eksplanatoris. 26

Kehadiran peneliti mutlak dilakukan untuk mengumpulkan data-data yang diperlukan dengan instrumen yang telah ditetapkan, baik berupa observasi dan wawancara. Kehadiran peneliti disadari dan diketahui oleh para informan karena hal itu tidak akan mengganggu pengumpulan data bahkan peneliti telah memperoleh izin.

Lokasi penelitian dalam penelitian ini adalah kantor pusat BPRS SPM Pamekasan untuk menggali data yang berkaitan dengan bank, sedangkan yang berhubungan dengan DPS maka lokasi penelitian di kediaman DPS yaitu KH. Lailurrahman (KLR) dan H. Moh. Zahid, M.Ag. (MZ).

Dalam penelitian kualitatif sumber data adalah kata-kata verbal dan tindakan. Selain itu bisa berupa dokumen dan data-data lain yang mendukung sebagai data tambahan yang akan mendukung data utama.27

Sumber data dalam penelitian ini dibagi menjadi dua, yaitu: pertama, primer meliputi para DPS yaitu KLR dan MZ yang bertugas untuk mengawasi operasionalisasi BPRS SPM agar sesuai dengan prinsip-prinsip syariah. Kedua, adalah pihak BPRS SPM sendiri yang dalam hal ini diwakili oleh direktur yaitu

\footnotetext{
25Imron Arifin, ed. Penelitian Kualitatif dalam Ilmu-Imu Sosial dan Keagamaan, (Malang: Kalimasahada Press, 1996), hlm. 57. ${ }_{26}$ Ibid.
} 
Bapak Surahman sebagi orang yang bertanggung jawab secara penuh terhadap BPRS SPM.

Teknik yang digunakan dalam penelitian ini ada tiga, yaitu:

a. Observasi

Observasi merupakan teknik pengumpulan data yang dilakukan dengan cara mengamati dan mencatat secara sistematis semua fenomen yang berhubungan dengan topik penelitian.28 Observasi non partisan yang dilakukan peneliti terhadap semua gejala yang ada baik BPRS SPM maupun para DPS untuk memberikan gambaran yang mendekati realita yang ada. Observasi yang dilakukan kepada para DPS adalah rekaman kiprah beliau di masyarakat sebagi user dari BPRS SPM baik sebagi nasabah maupun calon nasabah. Observasi terutama diarahkan kepada direktur yang sehari-hari bertangung jwab terhadap pengendalian BPRS SPM.

b. Wawancara

Wawancara yang dilakukan adalah mendalam dan terpimpin dengan mengajukan kisi-kisi, walaupun tidak rigid. Diharapkan dengan panduan kisi-kisi tersebut wawancara akan terarah sesuai dengan topik penelitian untuk mengungkap hal-hal yag diperlukan dalam penelitian ini. Wawancara dilakukan kepada para DPS dan Direktur bank. Semua kisi-kisi sudah diberikan. Mendalam yang dimaksudkan adalah wawancara yang pertama kalau dianggap ada data yang perlu dikaji lagi maka akan dilakukan wawancara baik secara langsung maupun dengan alat komunikasi. Hal itu dilakukan untuk mengefektifkan momen yang ada karena beliau rata-rata adalah orang-orang yang sibuk yang waktu begitu berharga.

Selanjutnya wawancara itu ditulis dalam catatan lapangan bahkan direkam dengan tujuan agar semua materi pembicaraan baik soal dan jwaban dapat terekam dengan utuh dan lengkap. Dari kertas dan rekaman itu akan dianalisis sesuai dengan topik penelitian yang dilakukan.

c. Dokumentasi 112.

27Lexy j. Moleong, Metodologi Penelitian Kualitatif (Bandung: Remaja Rosdakarya, 1990), hlm.

28Sutrisno Hadi, Metodologi Research(Yogyakarta: Andi Affist, 1990), hlm. 136.

jsh Jurnal Sosial Humaniora, Vol 5 No.1, Juni 
Berbicara dokumentasi di perbankan banyak dokumen-dokumen yang bersifat rahasia seperti kontrak antara nasabah dengan pihak bank seperti kontrak pembiayaan murabahah, mudharabah, dan lain sebagainya. Selain nasabah yang bersangkutan sehingga kami hanya diceritakan garis besarnya saja. Demikian juga hasil laporan dari DPS. Oleh karena itu kami hanya diyakinkan dengan melihat tanpa mencata apapun namun peneliti diberikan garis-garis besarnya. Namun seperti brosur, formulir yang tidak rahasia kami juga boleh mendokumentasikannya. Situasi seperti itu tidak akan mengurangi validitas data yang ada karena observasi itu merupakan data pendukung dimana data utamanya bisa didapatkan dengan interview yang mendalam.

Analisis yang dilakukan pada waktu pengumpulan data maupun sesudahnya. Hal itu dilakukan agar melengkapi data-data yang dianggap kurang. Pengumpulan data yang dilakukan dengan menuliskan, mengedit, mengklasifikasi, mereduksi dan menyajikan data. 29 Secara bertahap dilakukan analisis dalam tiga tahap yaitu: Pertama, reduksi data dengan menyederhanakan data kedalam konsep-konsep, kalsifikasi dan ciri-ciri yang ada. Kedua, sajian data merupakan proses uraian data dalam bentuk penjelasan verbal. Ketiga,

pengambilan kesimpulan dengan melihat data-data yang ada yang dikomunikasikan dengan teori yang ada untuk mencari temuan yang teoritis.

\section{Hasil Penelitian dan Pembahasan}

Dari data yang sudah di temukan maka perlu dianalisis. Pada bagian ini juga dibagi atas dua bagian, yaitu:

1. Operasionalisasi pengawasan oleh DPS terhadap BPR Syariah SPM di Pamekasan

Sebelum pada pengawasan maka perlu dibahas tentang DRS BPRS SPM. Formula DPS BPRS SPM mendekati sebuah idealisme karena formulanya lengkap baik dari segi ulama dan akademisi. Relasi diantara keduanya terjalin dengan baik sehingga dimungkinkan akan membawa efek yang positif terhadap pengawasan. Sedangkan relasi dengan pihak bank juga baik. DPS akan

29Muhajir, Penelitian Kualitatif..., hlm. 30.

is. Nasution, Metode Penelitian Naturalistik-Kualitatif (Bandung: Tarsito, 1992), hlm. 128-130. 
menemukan maslah jika antara DPS dan pihak bank mempunyai cara pandang yang berbeda. Namun di BPRS SPM DPS bukan haya difungsikan sebagai DPS melainkan guru. Sebuah figur yang tentunya segala sarannya akan dilakukan. Kalau nuansa ini ada di dalam pengawasan maka tidak akan ada kendala yang berarti.

DPS BPRS SPM sudah melakukan pengawasan yang maksimal. Dalam segi frekuensi sudah luar biasa. Bukan hanya setiap semester melakukan pengawasan sebagaimana yang diwajibkan melainkan seringkali bahkan secara pro aktif terhadap karyawan bank bahkan sampai nasabah bank. Sebuah kinerja yang patut dibanggakan.

Ada dua hal yang diawasi. Pertama, dokumentasi yang terkait dengan kontrak antara nasabah dan bank. Dalam bagian ini DPS telah berhasil menemukan beberapa pelanggaran dan telah disarankan untuk diubah. Misalnya memisah antara akad wakalah dengan murabahah. Karena dua akad tidak boleh bersatu dalam satu transaksi. Hal ini mudah dikoordiansikan karena hanya berkaitan dengan sisi administrasi sebuah bank dan mengahadapi karyawan yang nota bene punya tekad untuk menerapkan prinsip-prinsip syariah. Namun hal yang sulit diubah adalah tataran aplikasinya. Hal ini berhubungan dengan nasabah yang punya mind set sendiri. Harus diakui nasabah masih mempunyai mindset bank konvensional ketika bertransaksi dengan bank syariah sehingga di anggap salah kaprah.

Disisi lain adalah mahalnya kejujuran yang harus dipunyai kedua pihak yaitu bank dan nasabah. Di satu sisi bank harus transparan karena ia diawasi dan diperiksa oleh BI dan DPS. Setiap rupiah akan dicatat dan lengkap laporannya. Namun di sisi lain siapa yang berhak memeriksa nasabah. Inilah dilemasi yang mewarnai pengawasan oleh DPS. Problematika itu ada ketika DPS BPRS berhadapan dengan nasabah. Akan tetapi nasabah merupakan user yang terus harus dipelihara karena bagaimanapun bank perlu dukungan nasabah karena secara esensinya bank menggalang dana dari nasabah dan menyalurkan kepada nasabah. 
Dilihat dari hak dan kewajban DPS maka DPS BPRS SPM sudah memenuhi bahkan melampaui. Ia bukan hanya pengawas tetapi merangkap sebagai pihak yang mensosilasasikan keberadaan BPRS SPM khususnya dalam kekonsenan dibidang syariahnya bank.. Problematika di ranah nasabah ini ibaratnya memasuki gray area (area abu-abu) yang sulit dicarikan solusinya, namun DPS sepertinya melihat inilah tantangan yang harus dihadapi sebagai jihad dalm ranah perbankan dimana dalam perjuangan dipastikan adanya tantangan dengan prinsip fastabiqul khoirat.

2. Kontribusi DPS dalam ranah pengawasan BPR Syariah SPM Pamekasan sebagai usaha mensyari'ahkan BPR Syari'ah

Semua pihak tentunya diharapkan mempunyai kontribusi terhadap hal ini. Namun pihak yang paling bertanggung jawab adalah DPS karena ia merupakan pembeda pertama dan utama antara bank syariah dan konvensional serta ia yang menjamin bahwa sebuah bank syariah bergerak berdasarkan prinsip-prinsip syariah.

Batu sandungan yang cukup berarti adalah adanya opini yang masih menyangsikan eksistensi bank syariah. bank syariah dianggap hanya mengkreasi cara dan akhirnya sama dengan konvensional. Opini ini tidak bisa ditolak walaupun mungkin tidak bisa langsung diterima. Tidak bisa dinafikan walaupun mungkin tidak bisa ditelan mentah-mentah.

Kreatifitas dan usaha yang dialakukan oleh DPS bersama BPRS SPM merupakan sebuah langkah kongkret yang dimungkinkan akan meminalisir opini yang negatif tersebut. Tidak semua opini dijawab dengan opini. Namun dengan bukti, berbicara bukti maka waktu yang bisa menguraikan semua.

Ketika berbicara waktu maka tiga tahunan merupakan usaha yang masih relatif muda. Ditengah bank konvensional yang sudah menjadi darah daging dan mind set masyarakat. Akan tetapi dengan kinerja yang berpegang secara penuh kepada prinsip syariah maka suatu saat akan menghilangkan stigma itu walaupun mungkin tidak akan mampu menghilangkan sama sekali.

Dari data diatas dua hal yang terus di awasi, yaitu: pertama, admisnistrasi/kontrak. Semua nomenklatur yang ada harus disesuiakan dengan 
aturan dan petunjuk yang menerapkan prinsip-prinsio syariah seperti fatwa DSN MUI. Kedua, yang paling sulit aplikasinya agar disesuaikan dengan prinsip syariah.

Demikian juga dua pihak, yaitu nasabah dan bank harus mempunyai keinginan yang sama untuk bermuamalah sesuai syariah. Pihak bank tidak boleh bosan-bosan untuk mengedukasi mrasyarakat agar mengenal dan mau mengamalkan konsep syariah dalam perbankan. Di samping itu bank juga harus benar-benar konsisten untuk mengamalkan prinsip syariah dalam setiap operasionalisasinya.

Kontribusi DPS dan bank akan efektif jika mereka mendapatkan dukungan masyarakat muslim secara luas untuk mengawal penerappan syariah dalam perbankan, jika tidak maka keberadaan bank syariah akan terhalangi oleh opini dan mind set masyarakatnya sendiri.

\section{Penutup}

Pada bagian akhir tulisan ini perlu disimpulkan beberapa hal, yaitu:

1. Operasionalisasi pengawasan oleh DPS terhadap BPR Syariah SPM di Pamekasan

Secara sistematis pengawasan telah dilakukan oleh DPS terhadap BPRS SPM. Kalau laporan ke BI dilakukan setiap enam bulan sekali. Namun DPS melakukan pengawasan secara rutin minimal satu bulan satu kali dan secara langsung kepada karyawan dan nasabah bank.

Ada dua hal yang diawasi yaitu bagian administrasi meliputi transaksi kontrak anatara bank dan nasabah. Demikian juga hal yang penting yaitu aplikasinya. Secara prinsip di antara DPS tidak ada problem bahkan saling melengkapi. Relasi DPS dengan Bank tidak ada juga karena bank menganggap dirinya murid dan DPS lah gurunya sehingga siap melaksanakan semua saran dari DPS. Namun yang menjadi kendala adalah ketika mengedukasi masyarakat terutama tentang berusaha jujur dan transparansi didalam berinteraksi dengan bank. 
2. Kontribusi DPS dalam ranah pengawasan BPR Syariah SPM Pamekasan sebagai usaha mensyari'ahkan BPR Syari'ah

Ada kontribusi besar yang diberikan oleh DPS BPRS SPM dalam meningkatkan kesyari'ahan BPRS SPM. Hal itu adalah dengan melakukan pengawasan sekaligus pembinaan agar dalam semua operasional yang dilakukan oleh bank harus berpegang teguh pada prinsip-prinsip syariah.

Dalam rangka meminimalisir opini penyamaan bank konvensional dengan syariah maka perlu dilakukan usaha yang sungguh oleh DPS dengan terus menerus mengedukasi masyarakat dan karyawan bank.

Dari simpulan tersebut maka perlu direkomendasikan beberapa hal kepada beberapa pihak, yaitu:

\section{Untuk DPS}

Hendaknya lebih giat lagi dalam mensosialisasikan pengawasan yang dilakukan sebagai suatu ikhtiyar untuk menjamin syariahnya sebuah bank. Hal ini diperlukan media dan cara yang sistemik. Seperti radio dan schedule yang tertata denga rapi sehingga menghasilkan perubahan opini (mind set mayrakat).

2. Untuk Bank

Hendaknya lebih giat lagi dalam menggandeng pihak-pihak lain agar aktifitas kesyariahan yang dipraktikkan bisa dilihat dan didengar masyarakat sehingga menjadi alternatif bagi mereka didalam berinteraksi dengan bank.

Disisi lain peningkatan kapasitas karyawan baik keilmuan maupun mental sehingga ada keinginan menerapakn prinsip syariah dalam perbankan.

3. Untuk Masyarkat/Nasabah

Hendaknya tidak apriori terhadap bank syariah. masuk dulu, transaksi dulu dengan bank syariah baru beropini. Jika memang ada bank syariah yag tidak sesuai dengan prinsip syariah silahkan disampaikan sebagai bentuk amar ma'ruf nahi munkar.

4. Peneliti Selanjutnya

Bank syariah dengan segala dimensinya tetap menjadi sebuah kajian yang layak untuk diteliti. Masih banyak problem yang harus dipecahkan dengan sebuah 


\section{Daftar Pustaka}

Al Qur'an dan Terjemahnya.

Antonio, M. Syafi'i, 1993. Pengenalan Umum Bank Syari'ah, Jakarta: Tazkia Institute

Antonio, M. Syafi'i, 2001. Bank Islam: Dari Teori Ke Praktik. Jakarta: Gema Insani

Antonio, M. Syafi'i, 2007 Muhammad SAW: The Super Leader Super Manager.Jakarta: ProLM Centre.

Anwar, Syamsul, 2000 Permasalahan Produk Bank Syari'ah Sebuah Kajian Tentang Bay' Mu'ajjal Yang Berusaha Melihat Operasional Bank Syari'ah Dari Segi Produknya Di BPRS Bangun Drajat Wangin Bangun Tapa Yogyakarta. Yogyakarta: Laporan penelitian kelompok.

Arifin, Imron. ed., 1996 Penelitian Kualitatif dalam Ilmu-Ilmu Sosial dan Keagamaan. Malang: Kalimasahada Press.

Arifin, Zainul, 2000 Memahami Bank Syari'ah: Lingkup, Peluang, Tantangan dan Prospek. Jakarta: AlvaBet.

Arifin, Zainul, 2002 Dasar-Dasar Manajemen Bank Syari'ah. Jakarta: Alvabeta bekerjasama dengan Tazkia Institut.

Arifin, Zainul, 2009Perbankan Syari'ah, Jakarta: Bank Indonesia

Bank Indonesia. 2006 Kamus Istilah Keuangan Dan Perbankan Syari'ah. Jakarta: Direktorat Perbankan Syari'ah BI.

Bank Indonesia. 2010Perbankan Syari'ah, Lebih Dari Sekedar Bank. Jakarta: BI. DSN MUI-BI, 2001 Himpunan Fatwa. Jakarta: Gaung Persada.

Furchan, Arif, 1992. Metode Penelitian Kualitatif. Surabaya: Usaha Nasioanal

Hadi, Abd.,2009. Makna Keputusan Majlis Tarjih dan Tajdid Muhammadiyah tentang Bunga Bank bagi Pelaku Ekonomi Warga Muhammadiyah Surabaya. Disertasi IAIN Sunan Ampel Surabaya

Hadi, Sutrisno., 1990. Metodologi Research. Yogyakarta: Andi Affist. 
56 - Pro6lematika Pengawasan Bank Perkreditan rakyat Syariat di Pamekasan Zainal

http://www.scribd.com/doc/506978/syafii-antonio. Di akses 21 des 2010 pukul

$$
\text { 08.46 WIB. }
$$

Kartono, Kartini, 1996. Pengantar Metodoloi Riset Sosial. Bandung: Mandar Maju

Manulang M. , 2004 Pedoman Teknis Menulis Skripsi, Yogyakarta: Andi Masri Singarimbun (ed), 1989. Metode Penelitian Survei. Jakarta: LP3ES Materi Work Shop BPRS.

Moleong, Lexy J., 1990. Metodologi Penelitian Kualitatif. Bandung: Remaja Rosdakarya

Muhadjir. Noeng, 1996. Metode Penelitian Kualitatif. Yogyakarta: Rake Sarasin

Muhammad, 2002. Bank Syari'ah: Analisis Kekuatan. Peluang. Tantangan dan

Ancaman. Yogyakarta: Ekonisia

Muhammad, 2000.Lembaga Keuangan Kontemporer, Yogyakarta: UII Press Muhammad, 2005. Manajemen Dana Bank Syari'ah. Yogyakarta: Ekonisia Muslehuddin, Muhammad, 1994.Sistem Perbankan Dalam Islam. Jakarta: Rineka

Cipta

Nawawi, Hadari, 1994.Penelitian Terapan. Yogyakarta: UGM universitybPress

Perwataatmadja, Karnaen dan Antonio, M. Syafi'i., 1997Apa dan Bangaimana

Bank Islam. Yogyakarta: PT. Dana Bhakta Wakaf

S. Nasution. , 1992 Metode Penelitian Naturalistik-Kualitatif. Bandung: Tarsito.

Saidi, Zain. 2003. Penelitian Terhadap Praktik Perbankan Syari'ah. Jurnal Muamalah, Oktober 
Siregar, Mulya 2010. Strategi BI Kembangkan Perbankan Syai'ah dalam Majalah Sharia Insight edisi desember

Sudarsono, Hari, 2007. Bank dan Lembaga Keuangan Syari'ah: Diskripsi dan

Ilustrasi. Yogyakarta:Ekonisia

Surakmad Winarno,1980. Pengantar Penelitian Ilmiah dasar Metoda Tehnik, Jakarta: Tarsito

Utomo, Setiawan Budi, 2010. Peran DSN dan DPS dalam Perbankan Syari'ah

dalam Kumpulan Materi TOT Perbankan Syari'ah.Surabaya: IAIN Sunan

Ampel,

jsh Jurnal Sosial Humaniora, Vol 5 No.1, Juni 2012 